Elsevier Editorial System(tm) for Technovation: The International Journal of Technological Innovation, Entrepreneurship and Technology Management Manuscript Draft

Manuscript Number:

Title: Innovation Policy within Private Collectives: Evidence on 3GPP's Regulation Mechanisms to Facilitate Collective Innovation

Article Type: Research Paper

Keywords: collective innovation, private-collective, IP rights,3GPP, standards, antitrust, innovation policy

Corresponding Author: Dr. David Lopez,

Corresponding Author's Institution: University of Exeter

First Author: David Lopez

Order of Authors: David Lopez; Annabelle Gawer, PhD

Abstract: This article provides insights on how to manage collective innovation in the digital economy, an innovation regime which is riddled with complex regulatory challenges and increasing litigation over intellectual property rights. Private collective organisations face two main challenges: (1) to promote collective innovation while preserving the private interests of the firms within the collective, and (2) to ensure that collective innovation does not weaken healthy competition. Through a case study of the Third Generation Partnership Project (3GPP), an exemplary private collective federation of organisations composed of standardization bodies, industry consortia and technology producers, we identify organisational solutions to these challenges. We find that a combination of specific IP rights instruments is key to manage these trade-offs. We also find that the combined policies of essential patenting, FRAND, and maximum royalty rate help overcome the specific challenges associated with collective innovation within competitive contexts. Finally we discuss the implications of our findings for managers and for policy. 


\section{Innovation Policy within Private Collectives: Evidence on 3GPP's Regulation Mechanisms to Facilitate Collective Innovation}

\section{Introduction}

Innovation policy, aiming to enhance economic welfare benefits derived from innovation, has traditionally used three types of instruments: intellectual property rights (IPR), competition policy and budgetary incentives through taxes and subsidies. The logics behind these approaches are complementary: IPR is meant to protect innovators' financial incentives to innovate, whereas competition policy protects competition on the assumption that, once unleashed, competitive market forces constitute an effective mechanism to spur innovation. At the same time, governments regularly deploy taxes and subsidies to encourage innovative firms. Taken together, these instruments ensure that innovators, be they individuals or firms, can profit from commercializing their innovations (Teece 1986; Teece 2006), which feeds back into encouraging them to further innovate.

While these policy instruments have been developed in an economy largely reliant on manufacturing, today's economy raises different kinds of challenges with regards to innovation. In particular, innovations within the digital economy are parts of complex and interdependent technological systems, and mostly conducted in a distributed, collaborative manner (Yoo 2012). Digital industries are typically structured around platform-based ecosystems where firms collaborate and compete around modular components and interfaces (Gawer \& Cusumano 2002; Sanchez 1995). As a result, the management of IPR under collaborative innovation regimes becomes far more nuanced than in traditional contexts (Shapiro 2001).

Collective innovation, which is pervasive in the digital economy, creates complex regulatory challenges (Gawer 2012), as well as increasing litigation over intellectual property rights involving firms (Economist 2012; FT 2012; Forbes 2013a) as well as governments (FT 2013). In response to these phenomena, recent literature calls for new innovation policies that (1) better integrate private interests with public policy (Howells 2006; Shapiro 2008; Morlacchi \& Martin 2009; Flanagan et al. 2011) and (2) provide new instruments to regulatory bodies and firms facilitating collaborative innovation (de Jong et al. 2010; Ebersberger 2011; Levy \& Reid 2011).

This paper aims to make progress on these issues, by focusing on a unique case study in the telecom sector. The Third Generation Partnership Project (3GPP) is a federation of organizations comprising of standardization bodies from Asia, Europe and North America, industry consortia, technology producers including large firms such as Ericsson, Huawei, Motorola, Nokia, Qualcomm, and small firms, as well as large technology consumers such as telecommunication operators.

Since its creation in 1997, 3GPP has aimed to stimulate collective innovation while promoting the private interests of a number of partners who may be competitors as well as collaborators. It has therefore faced for a number of years some of the complex challenges that the public regulator is starting to face when aiming to promote innovation in the digital economy. 3GPP has been largely successful in its efforts, with 90\% of the 6 billion mobile subscribers using 3GPP-sponsored technologies (GSA 2013). Through a multi-method study combining interviews and a survey, we 
explore in this paper the regulation mechanisms through which 3GPP manages the trade-offs of: (1) aligning the private interests of the firms within the collective; (2) ensure that collective innovation does not weaken healthy competition.

We find that a combination of specific IP rights instruments is key to managing these trade-offs. Specifically, we find that the combined policies of essential patenting, FRAND, and maximum royalty rate help overcome the specific challenges associated with collective innovation within competitive contexts.

The paper contributes therefore to the literatures on private collective innovation and IP rights and helps bridge these literatures. Our contributions are the following. We contribute to the private collective literature as our paper is the first to our knowledge that explores empirically how the management of IP rights affects the ability of a private collective organization to both innovate and compete. We find that the manner in which IP rights instruments are implemented in practice has a profound impact on shaping the process and the outcome of collective innovation in private collective organizations.

Relevant to the IP rights literature, we extend this literature by assessing a study of the combination and the interaction of different IP rights mechanisms operate in the context of a private collective organization. Specifically, and contrary to results questioning the validity of FRAND (Treacy \& Lawrance 2008), we find that this instrument is beneficial both at the firm level and the collective level. We find however that essential patenting, as currently implemented in 3GPP, does not work the way it has been predicted (Shapiro 2001; Lemley 2002,2007) as is prone to subjective reinterpretation once standards and licensing agreements have been developed, which leads to possible hold-up situations and litigation.

We also contribute to the policy debate about IP rights in the context of collective innovation. Our empirical study reveals that a practical solution to the limitations of current essential patenting has been found and implemented in the context of 3GPP: it consists in associating essential patenting policies to an ex-ante maximum royalty rate policy, which limits ex-post opportunistic behavior. This practical solution raises some concerns however, given the possibility of maximum royalty rate to be interpreted as anti-competitive by current antitrust regulation. We therefore raise the question of re-examining the potentially negative impact of antitrust regulation on collective innovation. The adoption of this practical solution, currently advocated by a number of firms involved in 3GPP (LTE 2008), would require modifications in antitrust regulation and a more flexible approach to public policing of collective innovation. This paper therefore contributes to the innovation policy debate on the reform of the patent system and antitrust regulation (AMC 2007; Wright 2009; Zoettl et al. 2009) especially in the mobile sector (Balto 2004) by providing empirically-based insights in favor of examining the impact of competition policy on collective innovation challenges.

\section{Theory and hypotheses}

The private-collective model of innovation (von Hippel \& von Krogh 2003) describes a model of technology development that combines established models of proprietary innovation with some collective aspects of innovation whereby firms relinquish ownership rights over resources to make them partially non-excludable (Alexy \& Reitzig 2013). In the private-collective, firms contribute to 
the production of a common technology (e.g. mobile communications, open source software) exhibiting public good characteristics.

Private-Collective organizations can be considered a particular form of strategic alliance as firms engage in a web of agreements sharing the commitment to reach a common goal by pooling their resources and coordinating their activities (Teece 1992; von Hippel \& von Krogh 2006; Enkel et al. 2009; Huizingh 2011). In a similar manner to other sorts of strategic alliances, firms within the private-collective collaborate in research and development (Hagedoorn et al., 2000; Yasuda 2005), technology standardization and technology commercialization.

A unique characteristic of private-collective, however, is the creation of pools of intellectual property rights (IPrights) which are made available to the community within the private-collective.

The creation of shared patent pools have profound implications on innovation as, by partially waiving IP rights, firms within the private-collective reduce search and licensing transaction costs, as well as potential, ex-post, litigation (Von Hippel \& von Krogh 2003; Garud \& Kumaraswamy 1993; Fitzgerald 2006; Lerner \& Tirole 2002b).

By lessening licensing and litigation costs, firms within the private-collective are able to expand their strategic options for technology development; in addition to traditional appropriation mechanisms such as large portfolio patenting or technology manufacturing, firms are adopting alternative approaches focusing on developing a limited set of patents and contributing them to patent pools and standards with other firms (Fischer \& Henkel 2013).

Therefore private-collective as a model of innovation allows firms to implement strategies based on asset and knowledge specialization and value-capture strategies based on full technology package commercialization and IP rights. Examples of this model of innovation can be found in the software industry (von Krogh et al. 2003; Osterloh \& Rota 2007) as well as in service and manufacturing (van de Vrande et al. 2009).

In this sense the private-collective model of innovation is claimed by several authors as an effective organizational form to facilitate the development of markets for technology (Arora et al. 2004).

Firms, however, often fail to benefit from inter-firm partnering, especially in technological contexts riddled with complex intellectual property regimes (Somaya 2003; Somaya et al. 2011), information and power asymmetries (Das \& Teng 2000; Osborn \& Baughn 1990), opportunistic behaviour (Williamson 1998; Gulati 1995) and managerial complexity (Park \& Ungson 2001).

Reasons for the high failure rates observed in inter-firm partnering are, among others:the performance and network ties (Olk \& Young 1997), access to complementary resources, the evolution of the consortium itself (Hagedoorn et al., 2000; Hagedoorn 2002; Lunnan \& Haugland 2008) and the location of other strategic partners relative to the focal firm (Adner \& Kapoor 2010). This is especially the case in contexts in which transactions are established at a vertical level (e.g. supplier-provider) and at a horizontal level between competitors (e.g. cross-licensing).

As a result the firm's ability to create and capture value from partnering with others is contingent on its market power, internal resources, activities outside the private-collective (Leiponen 2008; 
Stuermer et al. 2009) and other firms, either internal or external, to the private-collective (Alexy \& Reitzig 2003).

Also of relevance in determining the success of any strategic partnering is the IPrights regime operating, especially if there are processes for standards development (Lemley 2002; Rysman \& Simcoe 2008) and large network effects involved in standards adoption (Shapiro 2008; Chiao et al. 2007; Schmalensee 2009).

Literature on standard settings and intellectual property rights find significant weaknesses in current regimes for the management of IPrights that can provide perverse incentives for patent licensing firms to seek excessive rates of return as well as for licensees to minimize the economic value of the innovation embedded in the patent (Lichtman 2010; Treacy \& Lawrance 2008; Schmalensee 2009 ).This not only impedes efficient markets for technology (Arora et al. 2004) but at the same time exposes the private-collective to exogenous stakeholders such as governmental agencies, antitrust and other legal systems (Lemley \& Shapiro 1991; Lemley 2002, 2007) whose decisions can have a profound impact on the firm's ability to innovate and extract economic value from it.

In this regard this paper aims to contribute to a further understanding of the context that makes private-collective a sustainable model of collaborative innovation. More precisely, this paper investigates: (1) internal mechanisms of governance of IPrights whereby private-collective institutions can develop technologies and the resulting ability of the firm to benefit from them, as well as (2) the interplay between cooperation and competition in the context of private-collective. The former aspect is developed in section 2.1 with the latter in section 2.2.

From a public policy perspective, providing insights on these matters is relevant given current debates on the reform of the patent system and antitrust regulation (AMC 2007; Wright 2009; Zoettl et al. 2009) especially in the mobile sector (Balto 2004).

From a strategic and managerial perspective a better understanding of private-collective as a model of collaborative innovation would help firms' managers to better assess positioning and coordination choices (lansiti and Levien 2004), value chain configuration in the private-collective (Adner and Kapoor 2010) and the benefits, and risks, associated with adopting a private-collective model (Joshi \& Nerkar2011).

\subsection{Coordination of innovation in the private-collective (First trade-off: coordination of collective innovation \& proprietary innovation)}

The development of technologies within a Private-Collective organization involves a combination of many different components each of which may be the subject of one or more patents. In the information technology sector in particular, high-technology products such as microprocessors, cell phones, or memory devices can easily be covered by dozens or even hundreds of different patents.

The fact that a large set of patents can affect a single technology creates a patent thicket (Shapiro 2001 ) in which a set of patents, owned by different firms, overlap around the same technology. This might lead to complex patent hold-up situations resulting in (1) injunction threats and (2) royalty stacking. 


\subsection{1: Injunction threats}

Lemley (2007) shows that the threat of an injunction can enable a patent holder to negotiate royalties far in excess of the patent holder's true economic contribution, ideally represented as a reasonable royalty level.

The royalty rate that would be reasonable and expected in the ideal patent system, without any element of hold-up is contingent on factors such as the value of the patented feature for the downstream firm, the margin per unit earned by the downstream firm on its product, the strength of the patent, the cost to the downstream firm of redesigning its product to avoid infringing the patent claims as well as the bargaining skills of the patent holder among others.

The negotiated royalty rate, however, depends upon the downstream firm's best strategy in the event that negotiations with the patent holder break down. In the case of litigation the owner of the patent gains great bargaining leverage from its ability to threaten to force the downstream firm from the market if the patent is found valid and infringed (Shapiro 2008). An alternative would be for the accused infringer to avoid the risk of disruption in its business by redesigning the product even while litigating, particularly if the cost of redesign is relatively low in comparison with profits that the downstream firm would lose by withdrawing from the market while redesigning its product. In any case, the patent holder benefits greatly from the fact that the downstream firm's threat point in the negotiations involves incurring redesign costs.

The threat that a patent holder will obtain an injunction that will force the downstream producer to pull its product from the market can be very powerful. These threats can greatly affect licensing negotiations, especially in cases where the injunction is based on a patent covering one small component of a complex, profitable, and popular product (USITC 2013; Economist 2013). Some situations of this phenomenon can be found in the mobile industry in which Apple and Samsung, formerly engaged in collaborative innovation, have recently resorted to litigation over IP rights (Forbes 2013a).

A number of private-collective institutions have adopted open policies of IP rights management whereby firms abide to a complete waiver of their patents. In what is known as the open source movement, patents associated with actual, or derived, innovations remain open and free for everyone to use (Lakhani \& von Hippel 2003; Lerner \& Tirole 2002a). Arguably this model of IP right management greatly diminishes risks associated with injunction threats.

In other instances of private-collective modes of innovation the excessive bargaining power hold by patent owners is compensated via two mechanisms: Essential patents and FRAND licensing (Lemley 2007; Farrell et al. 2007).

Patents are considered essential if they are considered to be indispensable to manufacture a standard-compliant technology (Bekkers et al. 2011). More precisely essentiality is a characteristic by which it is not possible on technical grounds to make, sell, lease otherwise dispose of, repair, use or operate equipment or methods which comply with a standard without infringing on that IPR (ETSI 2013). 
Essential patents not only address the injunction problem but also define technical interfaces required to ensure ex-post interoperability at a vertical (between subcomponents) and horizontal (among competitors) level.

Under a FRAND policy of licensing, firms within the private-collective abide to license on a Fair, Reasonable and Non Discriminatory (i.e., FRAND) basis. This mechanism is especially important in the case of essential patents as it effectively limits the monopolistic power which is granted to the owner of the essential patent (Lemley \& Shapiro 1991).

\subsubsection{Royalty stacking}

Royalty stacking refers to situations in which a single product potentially infringes on many patents, and thus may bear multiple royalty burdens. The term "royalty stacking" reflects the fact that, from the prospective of the firm making the product in question, all of the different claims for royalties must be added or "stacked" together to determine the total royalty borne by the product if the firm is to sell that product free of patent litigation. The existence of such "royalty stacking" exacerbates the hold-up problem as downstream firms (1) face infringement claims from multiple owners and (2) are charged more than the marginal costs associated to each patent (Shapiro 2001). Moreover royalty stacking may lead to a situation in which output is depressed even below the level that would be set by a vertically integrated monopolist.

In regards to the royalty stacking problem, firms engaged in the private-collective establish a maximum royalty rate for the technology as a whole (e.g. smartphone) thus avoiding potential unsustainable situations (Franzinger 2003).

These three mechanisms (Essential patenting, FRAND licensing and maximum royalty rates) make possible the implementation of pools of IP rights within the private-collective upon which collaborative innovation can take place ${ }^{1}$. We contend therefore that these mechanisms are critical for the sustainability and effectiveness of private-collective modes of innovation.

In order to empirically test the influence of these mechanisms in the governance of private-collective modes of innovation, we suggest the following hypotheses:

H1a. FRAND licensing is positively associated with firms' perception of their ability to develop technologies under Private-Collective contexts.

H1b. Essential patents are positively associated with firms' perception of their ability to develop technologies under Private-Collective contexts.

H1c. Maximum royalty rate policies are positively associated with firms' perception of their ability to develop technologies under Private-Collective contexts.

\footnotetext{
${ }^{1}$ We note in passing that open sourcing can be considered as a particular instance of IP right pooling in which FRAND is a "de facto" policy and there are no royalties associated at all
} 


\subsection{Coordination and competition in the private-collective (Second trade-off: coordination of collective innovation \& competition)}

Previous section hypothesizes the relevance of Essential patents, FRAND licensing and maximum royalty rates in private-collective modes of innovation. These mechanisms can (1) nurture innovation and technology improvement and (2) promote compatibility at a horizontal and vertical level. In the case of mobile technologies a consumer can substitute one brand of smartphone for another in the same mobile network; in a similar manner smartphone manufacturers can be reassured that their products will operate across mobile networks (Hovenkamp 2007). In this sense section 2.1 contends the beneficial effect of the three mechanisms in reducing transaction costs involved in presence of overlapping IP rights (i.e. patent thickets).

These instruments however may run counter to competition, therefore raising antitrust concerns. Essential patents, a set of technical specifications agreed within the private-collective that provides a common design for a technology, may facilitate both collusion and exclusion (Lemley 2002).

Collusion is possible as an essential patent, by definition, minimizes differentiation and makes technologies readily observable which in turn facilitates the emergence of cartels (Hovenkamp 2005; Scherer \& Ross 1990; Viscusi et al. 2005).

Conferring the status of essentiality to a certain set of patents arguably entails some exclusionary risks as owners of essential patents can exert excessive market power given the cumulative nature of technological development (ref to cumulative innovation), significant network effects (ref: network externalities) and patent hold-up (Lemley 2007). Previous section presented FRAND licensing as a counterbalancing mechanism to limit the exclusionary power granted by an essential patent.

Established competition rules on horizontal cooperation agreements explicitly prohibit agreements which have as their object the restriction of competition. For there to be restrictive effects on competition, essential patent and maximum rate policies must have, or be likely to have an appreciable adverse impact on at least one of the parameters of competition on the market, such as price, output, product quality and variety, or innovation (Whish \& Bailey 2012; EC2013).

From a practical perspective established legal practises, e.g. the European Union (EC2013), implement four cumulative conditions which must be met for co-operation agreements to be considered beneficial in the sense of providing efficiency gains offsetting potential restriction on competition, (1) must lead to economic benefits, (2) restrictions must be indispensable to generate efficiency gains, (3) consumers must receive a fair share of the resulting efficiency gains, (4) the agreement must offer the parties no possible elimination of competition in relation to a substantial part of the products in question.

Hypotheses $\mathrm{H} 1$ a to $\mathrm{H} 2 \mathrm{c}$ partially apply these four criteria to test any potential restriction on competition due to essential patenting, FRAND licensing and maximum royalty rate policies. Based on the analysis above, we contend that:

H2a. FRAND licensing is positively associated with firms' perception of their ability to compete in Private-Collective contexts. 
H2b. Essential patenting is positively associated with firms' perception of their ability to compete in Private-Collective contexts.

H2c. Maximum royalty rate policies are positively associated with firms' perception of their ability to compete in Private-Collective contexts.

\section{Data collection and analytical methods}

Our hypotheses require the identification of a setting in which firms federate around a privatecollective organizational form for the purposes of technological development and commercialization.

To adequately characterize the impact of IPrights mechanisms on innovation (hyp. $\mathrm{H} 1_{\mathrm{a}-\mathrm{c}}$ ) we need data corresponding to private-collectives that have formal mechanisms in place, patent licensing firms and patent licensees. In order to do a similar analysis, this time applied to competition (hyp. H2 a-c), we also need an instance of a private-collective in which firms engage in collaborative research whilst competing in subsequent stages of technology commercialization.

\subsection{The setting: 3 GPP}

The third Generation Partnership Project (3GPP) provides a setting that uniquely lends itself to the test of our hypotheses is the third Generation Partnership Project (3GPP). It is composed of standardization bodies from Asia, Europe and North America (ARIB, ATIS, CCSA, ETSI, TTA, TTC), market representation partners (IMS forum, IPv6 forum, UMTS forum, GSM association) as well as patent-intensive multinationals (Ericsson, Huawei, Motorola, Nokia, Qualcomm), technology consumers (e.g. telecommunication operators) and small technology-intensive firms.

In this domain, as documented in 3GPP (2007) and Leiponen (2008), 3GPP produces Technical Specifications, to be transposed by relevant Standardization Bodies into appropriate deliverables (e.g., standards).

3GPP inherited most of its operating procedures from the European Telecommunications Standards Institute (ETSI), retaining their approach to open membership, mechanism for the management of intellectual property rights, committee structure and working procedures, ETSI (2013). Contrary to ETSI, however, 3GPP is a clear departure from the government-led approach to technical standardization as in this case technological development is leaded by private firms.

Mandated by the International Telecommunications Union (ITU), 3GPP members start working collaboratively on the development of a new set of technical specifications (e.g., $4^{\text {th }}$ generation mobile) which are in turn transposed by standardization bodies into formal standards. With standards in place private firms are able to start competing in the market mostly based on price and value-added offerings (service and support, complementary technologies).

Market figures seem to support 3GPP as an effective institution to develop technological markets with circa six thousand million mobile subscriptions globally using 3GPP systems which makes $90 \%$ of the total mobile market today (Economist 2012b; Forbes 2013b; GSA 2013) 


\subsection{Data}

Initially a list of firms involved in 3GPP for the past decade was collected in order to conduct an analysis of their research intensity, as measured by number of conventional patents, essential patents (Bekkers et al. 2011; Phelps \& Milone 2012) and engineers assigned to work on 3GPP-related technology development (3GPP 2013b).

A preliminary analysis of the dataset reveals the existence of three different groups based on the number of engineers firms commit to developing technologies within 3GPP, the number of total patents related to mobile technologies, the number of essential patents and the number of years that the firm has been involved in 3GPP. Table 1 depicts a clear separation in three categories: (1) firms exhibiting high research intensity (measured in terms of patent portfolio, essential patents and engineers); (2) firms with lower levels of research intensity but similar periods of involvement; (3) firms with shorter periods of involvement and resources committed, (see Table 1).

Further analysis, reveals that group 1 corresponds to large firms (e.g. Ericsson, Samsung, Nokia) specialized in developing and commercializing new mobile technologies whereas group 2 corresponds to large firms (e.g. Japan Telecom, China Unicom, O2) whose main business model is based on providing mobile services to end customers. The third group is consisted of small firms with specialized technologies (e.g., security, geopositioning) and lower capacity for research.

Table 1. Initial analysis of firms participating in 3GPP

\begin{tabular}{ccccc} 
Group & $\begin{array}{c}\text { Number of } \\
\text { mobile related } \\
\text { patents }\end{array}$ & $\begin{array}{c}\text { Number of mobile related } \\
\text { essential } \\
\text { Patents }\end{array}$ & $\begin{array}{c}\text { Number of } \\
\text { engineers } \\
\text { involved }\end{array}$ & $\begin{array}{c}\text { Number of } \\
\text { Years } \\
\text { Involved }\end{array}$ \\
\hline Large Producers & 5105.826 & 30.60606 & 21.48485 & 6.909091 \\
Large Consumers & 1294.444 &. & 8.714286 & 5.142857 \\
Small Producers & 40 &. & 2.5 & 2.833333
\end{tabular}

A multivariate analysis of variance (MANOVA, Wooldridge 2012) confirms the existence of three different categories, according to the $p$-values obtained $(0.0282<0.05)$ (see Table 2 ).

Table 2. MANOVA analysis of firms involved in 3GPP

Number of obs $=32$

$\mathrm{W}=$ Wilks' lambda $\quad \mathrm{L}=$ Lawley-Hotelling trace

$\mathrm{P}=$ Pillai's trace $\quad \mathrm{R}=$ Roy's largest root

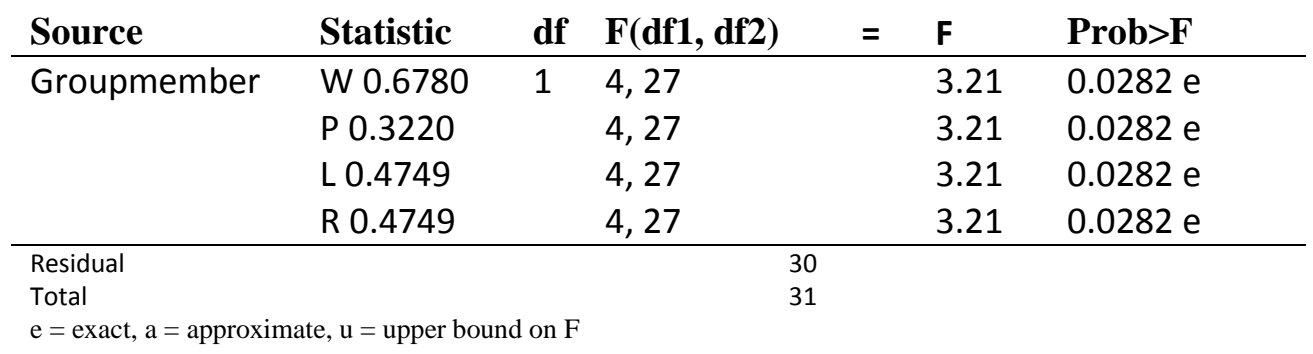




\subsection{Interviews}

For the purposes of triangulating among different sources of evidence, in addition to a quantitative analysis, a series of one-to-one interviews were arranged with relevant stakeholders. In total 6 indepth interviews with managers from Ericsson (2) and ETSI (2), a civil servant at the European Union involved in antitrust matters and one engineer formerly involved in standardization processes at 3GPP.

The interviews offered a rich perspective of 3GPP confirming the existence of several mechanisms formally established among the 3GPP community: Essential patent mechanism, FRAND licensing obligation in the case of essential patents and consensus-based decision making among others. Maximum royalty rate policy is a mechanism which, if not formally made explicit in 3GPP's procedures, is broadly agreed among firms in parallel negotiations according to experts interviewed.

\subsection{Survey}

Given the existence of three groups of firms with potentially conflicting interests (see Table 1) we conduct three different surveys, one for each group identified (large producers, large consumers, small producers). Preliminary interviews conducted prior to the survey lead us to be attentive to the difference between managerial roles (e.g. legal, strategy) and technical roles (e.g. engineers).

The survey was circulated electronically to a total of 205 representatives of the large producer category (e.g. engineers working at Nokia, Ericsson, Qualcomm, Alcatel-Lucent), 123 representatives of the large consumer category (e.g. Vodafone, ATT, France Telecom) and 40 from the small producer category. The response rate was $28.3 \%, 23.6 \%$ and $0.05 \%$ respectively. Unfortunately, the lack of sufficient responses from the small producer category leads us to eliminate this group from subsequent analysis.

3GPP, in a similar manner to other Private-Collective organizations, needs to address two main trade-offs for sustainable technology developments and subsequent diffusion to market: on the one hand it must find an adequate balance between coordination of collective innovation and firm's private interests, on the other hand it must ensure that collective innovation does not impede competition (and thus avoid antitrust concerns).

In regards to the first trade-off, we ask to a representative sample of the 3GPP community their preference, on a Likert scale, for each IPrights mechanism in terms of diffusion of the focal firm's innovations (Q3), as well as innovation activity resulting within the private-collective (Q4). Refer to Table 3 for more details on the questionnaire.

In regards to the second trade-off, we ask to the same set of respondents how they find the three coordination mechanisms under consideration in terms of the ability of the firm to compete (Q1), to protect their innovation (Q2), the ability of the private-collective to develop new markets (Q5), the ability of the private-collective to protect innovations from external infringement (Q6) and facilitating the development of alternative technology offerings (Q7).

Finally respondents rate, on a Likert scale, their overall perception of 3GPP as an effective institution in terms of innovation and competition $\left(Q 8, Q 8^{\prime}, Q 9^{\prime} Q 9^{\prime}\right)$. This approach is in the tradition of earlier empirical studies that relied on subjective assessments of the effectiveness of appropriability mechanisms (Cohen et al. 2000; Fisher \& Henkel 2012). 
In addition to controlling for the firms' strategic positioning (via the categorization into three categories), the results of preliminary interviews justified defining another variable (Role) controlling for the role played by the respondent in the firm (i.e. technical versus managerial). Finally a third variable, "Layer", controls for the respondent's experience in lower layers of 3GPP (e.g. radio transmission) versus higher ones (e.g. charging and billing, internet) (see Table 3).

Table 3. Survey instrument

\begin{tabular}{|c|c|c|c|c|}
\hline Variable & Sub variables & Dimension measured & $\begin{array}{l}\text { Unit of } \\
\text { analysis }\end{array}$ & Values \\
\hline Q1 & $\mathrm{Q} 1_{1}, \mathrm{Q}_{2}, \mathrm{Q}_{3}, \mathrm{Q1}_{4}$ & $\begin{array}{l}\text { Impact of each mechanism on the firm's } \\
\text { ability to compete }\end{array}$ & \multirow{3}{*}{ Private } & \multirow{11}{*}{$\begin{array}{l}\text { 5-point likert } \\
\text { scale } \\
\text { (strongly } \\
\text { disagree- } \\
\text { strongly } \\
\text { agree) }\end{array}$} \\
\hline Q2 & $\mathrm{Q} 2_{1}, \mathrm{Q} 2_{2}, \mathrm{Q}_{3}, \mathrm{Q}_{2}$ & $\begin{array}{l}\text { Impact of each mechanism on the firm's } \\
\text { ability to protect their innovations }\end{array}$ & & \\
\hline Q3 & $\mathrm{Q} 3_{1}, \mathrm{Q}_{2}, \mathrm{Q}_{3}, \mathrm{Q} 3_{4}$ & $\begin{array}{l}\text { Impact of each mechanism on the firm's } \\
\text { ability to diffuse their innovations }\end{array}$ & & \\
\hline Q4 & $\mathrm{Q}_{1}, \mathrm{Q}_{2}, \mathrm{Q}_{3}, \mathrm{Q}_{4}$ & $\begin{array}{l}\text { Impact of each mechanism on the ability } \\
\text { of the collective as a whole to solve } \\
\text { important technical problems? }\end{array}$ & \multirow{8}{*}{ Collective } & \\
\hline Q5 & $\mathrm{Q}_{1}, \mathrm{Q} 5_{2}, \mathrm{Q} 5_{3}, \mathrm{Q} 5_{4}$ & $\begin{array}{l}\text { Impact of each mechanism on the ability } \\
\text { of the collective as a whole to collectively } \\
\text { create new markets }\end{array}$ & & \\
\hline Q6 & $\mathrm{Q} 6_{1}, \mathrm{Q} 6_{2}, \mathrm{Q}_{3}, \mathrm{Q} 6_{4}$ & $\begin{array}{l}\text { Impact of each mechanism on the ability } \\
\text { of the collective as a whole to protect } \\
\text { internal innovations from infringement } \\
\text { or unfair competition }\end{array}$ & & \\
\hline Q7 & $\mathrm{Q} 7_{1}, \mathrm{Q7}_{2}, \mathrm{Q7}_{3}, \mathrm{Q7}_{4}$ & $\begin{array}{l}\text { Impact of each mechanism on the ability } \\
\text { of the collective as a whole to facilitate } \\
\text { different technology offerings from } \\
\text { competing firms? }\end{array}$ & & \\
\hline Q8 & & $\begin{array}{l}\text { Does 3GPP stimulate innovation and } \\
\text { technology development in the mobile } \\
\text { industry. }\end{array}$ & & \\
\hline Q8' & & $\begin{array}{c}\text { Does 3GPP help firms to innovate and } \\
\text { develop technologies in the mobile } \\
\text { market? }\end{array}$ & & \\
\hline Q9 & & $\begin{array}{l}\text { Does 3GPP stimulate competition in the } \\
\text { mobile market? }\end{array}$ & & \\
\hline Q9' & & $\begin{array}{l}\text { Does 3GPP help my firm to compete in } \\
\text { the mobile market? }\end{array}$ & & \\
\hline Group & & $\begin{array}{l}\text { Firm's strategic positioning (technology } \\
\text { producer, technology consumer) }\end{array}$ & & $(0,1)$ \\
\hline Role & & $\begin{array}{l}\text { Respondent's role in the company } \\
\text { (technical versus managerial) }\end{array}$ & & $(0,1)$ \\
\hline Layer & & $\begin{array}{c}\text { Respondent's experience in 3GPP (lower } \\
\text { layer, upper layer, both) }\end{array}$ & & $(0,1,2)$ \\
\hline
\end{tabular}




\section{Empirical results}

\subsection{Coordination of innovation}

Table 4 reports summary statistics for the variables considered in regards to coordination of collective innovation, measured via questions $\mathrm{Q} 3, \mathrm{Q} 4, \mathrm{Q} 8$ and $\mathrm{Q}^{\prime}$. The results as described below provide evidence supporting FRAND, essential patenting and maximum royalty rate policy as beneficial for innovation purposes in 3GPP (hyp.H1).

The preliminary analysis of data presented in section 3.3 revealed a large heterogeneity of members involved in 3GPP with three main groups: large technology producers, large technology consumers and small firms (the latter not being considered due to lack of sufficient data available). In order to test for any significant difference we entertain an ordered logit regression controlling for the variables Group, Layer and Role. Thus Table 5 represents the proportional odds ratios for a one unit increase in the control variables Role, Layer and Group on the dependent variables (Q3, Q4).

Table 4.Impact of mechanisms for Coordination of innovation in 3GPP (descriptive analysis)

Quantile

\begin{tabular}{|c|c|c|c|c|c|c|c|}
\hline & \multirow[b]{2}{*}{ Variable } & \multirow[b]{2}{*}{$\mathbf{N}$} & \\
\hline & & & Min & .25 & Median & .75 & Max \\
\hline $\begin{array}{l}\text { Essential } \\
\text { patents } \\
\text { (private) }\end{array}$ & Q31 & 87 & 2.00 & 3.00 & 3.00 & 4.00 & 5.00 \\
\hline $\begin{array}{c}\text { Essential } \\
\text { patents } \\
\text { (collective) }\end{array}$ & Q41 & 87 & 2.00 & 3.00 & 4.00 & 4.00 & 5.00 \\
\hline \multirow{2}{*}{$\begin{array}{l}\text { FRAND } \\
\text { (private) }\end{array}$} & Q32 & 87 & 3.00 & 3.00 & 4.00 & 4.00 & 5.00 \\
\hline & Q33 & 87 & 3.00 & 3.00 & 4.00 & 4.00 & 5.00 \\
\hline \multirow{2}{*}{$\begin{array}{l}\text { FRAND } \\
\text { (collective) }\end{array}$} & Q42 & 87 & 2.00 & 3.00 & 4.00 & 4.00 & 5.00 \\
\hline & Q43 & 87 & 1.00 & 3.00 & 4.00 & 4.00 & 5.00 \\
\hline $\begin{array}{c}\text { Maximum } \\
\text { Royalty rate } \\
\text { (private) }\end{array}$ & Q34 & 87 & 2.00 & 3.00 & 3.00 & 4.00 & 5.00 \\
\hline $\begin{array}{l}\text { Maximum } \\
\text { Royalty rate } \\
\text { (collective) }\end{array}$ & Q44 & 87 & 2.00 & 3.00 & 4.00 & 4.00 & 5.00 \\
\hline \multirow{2}{*}{$\begin{array}{l}\text { 3GPP and } \\
\text { innovation }\end{array}$} & Q8 & 87 & 2.00 & 3.00 & 4.00 & 5.00 & 5.00 \\
\hline & Q8' & 87 & 3.00 & 3.00 & 4.00 & 4.00 & 5.00 \\
\hline
\end{tabular}


Table 5.Influence of the control variables Role, Layer, Group (ordered logit)

\begin{tabular}{|c|c|c|c|c|c|c|c|c|c|c|}
\hline \multirow[b]{2}{*}{$\begin{array}{l}\text { Control } \\
\text { variable }\end{array}$} & \multicolumn{2}{|c|}{ Essential Patents } & \multicolumn{4}{|c|}{ FRAND } & \multicolumn{2}{|c|}{$\begin{array}{l}\text { Maximum royalty } \\
\text { rate }\end{array}$} & \multicolumn{2}{|c|}{$\begin{array}{l}\text { Overall } \\
\text { perception: 3GPP } \\
\text { and innovation }\end{array}$} \\
\hline & $\begin{array}{c}\text { Collective } \\
\text { level } \\
\text { (Q31) }\end{array}$ & $\begin{array}{l}\text { Firm level } \\
\text { (Q41) }\end{array}$ & $\begin{array}{c}\text { Collective } \\
\text { level } \\
\text { (Q32) }\end{array}$ & $\begin{array}{l}\text { Firm level } \\
\text { (Q33) }\end{array}$ & $\begin{array}{c}\text { Collective } \\
\text { level } \\
\text { (Q42) } \\
\end{array}$ & $\begin{array}{c}\text { Firm level } \\
\text { (Q43) }\end{array}$ & $\begin{array}{c}\text { Collective } \\
\text { level } \\
\text { (Q34) }\end{array}$ & $\begin{array}{c}\text { Firm level } \\
\text { (Q44) }\end{array}$ & Q8 & Q8' \\
\hline Role & $\begin{array}{l}32.1 * * * \\
(28.1)\end{array}$ & $\begin{array}{l}22.5 * * * \\
(17.3)\end{array}$ & $\begin{array}{l}12.7^{* *} \\
(10.9)\end{array}$ & $\begin{array}{l}98.5 * * * \\
(97.5)\end{array}$ & $\begin{array}{l}18.6 * * * \\
(16.0)\end{array}$ & $\begin{array}{l}10.7^{* * *} \\
(7.4)\end{array}$ & $\begin{array}{l}4.21^{* *} \\
(3.0)\end{array}$ & $\begin{array}{l}7.04 * * * \\
(5.1)\end{array}$ & $\begin{array}{l}6.16^{* *} \\
(4.2)\end{array}$ & $\begin{array}{l}40.8 * * * \\
(33.5)\end{array}$ \\
\hline Layer & & & & & $\begin{array}{l}1.79 * * \\
(0.54) \\
\end{array}$ & & & & & $\begin{array}{l}0.55 * * \\
(0.15) \\
\end{array}$ \\
\hline Group & $\begin{array}{l}5.6 * * * \\
(2.88) \\
\end{array}$ & $\begin{array}{l}2.4 * * \\
(1.1)\end{array}$ & $\begin{array}{l}5.6 * * \\
(3.2)\end{array}$ & & & & $\begin{array}{l}3.7 * * * \\
(1.8)\end{array}$ & $\begin{array}{l}4.05 * * * \\
(2.03)\end{array}$ & & \\
\hline $\begin{array}{l}\text { Prob> } \\
\text { chi2 }\end{array}$ & 0.000 & 0.000 & 0.000 & 0.000 & 0.000 & 0.000 & 0.012 & 0.004 & 0.036 & 0.000 \\
\hline
\end{tabular}

\subsubsection{Essential patent mechanism}

As far as the essential patent mechanism is concerned the results presented in Table 4 indicate a general consensus on its relevance for innovation purposes for the collective (Median Q4 ${ }_{1}=4$ ) with less support at the firm level (Median $\mathrm{Q} 3_{1}=3$ ).

We note a statistically significant influence of being a manager and a high scoring of the essential patent mechanism as an innovation enabler at both the firm and the collective level (32.1 and 22.5 respectively) (see Table 5). There exists some differences between the type of company under consideration as large technology consumers (e.g. telcos) exhibit larger odds of scoring essential patent as an important mechanism compared to technology producers(5.6 and 2.4 respectively).

According to an interviewee "The existence of essential patents is a two-edged sword. It is good that patents are classified as essential as then limits can be set on the amount of money that are charged for those patents (via FRAND). The problem with essential patents is that companies spend time in 3GPP trying to get their essential patents adopted, whether that is for the common good or not. This slows down the agreement process (as companies will hold out to the last to get their patented technology accepted)... the 3GPP process can be glacial because of essential patents and some odd decisions are made because of them".

Associated costs to essential patenting are mostly borne exclusively by the large producer group (the owners of essential patents) whereas large consumers benefit from a well-defined legal and technological context delineated by the essential patent mechanism, this would support the different perception observed in relation to the essential patent mechanism.

According to the results of the research the essential patent mechanism seem to play several roles in the process of collective innovation, (1) provides a legal instrument to ensure a return on investment on innovations, (2) delineates intellectual property rights around precise bundles of technologies (e.g. LTE in $4^{\text {th }}$ generation), (3) ensures technical interoperability by defining a technological 
standard. Hence we obtain support for the mechanism of essential patent as a relevant enabler of collaborative innovation in 3GPP (H1.b).

\subsubsection{FRAND mechanism}

The results presented in Table 4 reveal a strong support of FRAND as a relevant mechanism for facilitating innovation within $3 \mathrm{GPP}$ both at the firm level (Median: $\mathrm{Q} 3_{2}=4, \mathrm{Q} 3_{3}=4$ ) and the collective one (Median: $\mathrm{Q}_{2}=4, \mathrm{Q}_{3}=4$ ) .

The interviews conducted reveal that FRAND plays an important role in ensuring a collaborative environment in which innovation and technology development can take place.

As mentioned by one of the ETSI member interviewed"....3GPP tries to balance the private interests of the firms and the collective mostly via consensus-based decision making and FRAND licensing policies.... if someone is not prepared to license an essential technology following a FRAND policy then that technology is removed from the standard".

This official policy of establishing compulsory FRAND licensing in the case of essential patents emerges as a key governance mechanism within 3GPP to avoid hold-up situations such as the one documented in (ref. Rambus). Also compulsory FRAND licensing provides a limit to the power extended to any essential patent holder.

In this sense we observe a clear complementary role between the FRAND mechanism and the essential patent mechanism as both are required to overcome hold-up situations (Shapiro 2001, 2008) and thus foster collaborative innovation in private-collective contexts.

Based on the results presented in Table 5 we notice a statistically significant influence on the control variable Role on the odds of a high scoring of FRAND at a firm level $(12.7,98.5)$ and at a collective level $(18.6,10.7)$. This result suggests that managers involved in 3GPP exhibit stronger appreciation than engineers for FRAND as a strategic mechanism for innovation in the private-collective.

As far as the other control variables Layer and Group are concerned, the results lead us to conclude that there are no statistically significant differences neither among the type of company (technology producers vs. technology consumers) nor the layer in which the interviewee has been involved (5.6, 2.4).

Both empirical results and personal interviews conducted among experts in the field support FRAND as an innovation enabler in private-collective contexts (H1.a), moreover it seems to be a general consensus among firms and technological contexts on the importance of this mechanism.

\subsubsection{Maximum royalty rate}

Maximum royalty rate policies are not part of the 3GPP model of governance in order to avoid potential antitrust measures. Moreover all of the people interviewed who are directly involved with 3GPP, EU legislation and ETSI employees, preferred not to comment on the implications of having maximum royalty rates. However some of them indirectly expressed the necessity of limiting the potential of licensing revenues accruing for an essential patent: "You have to make sure that the cost of IP of each product or technology is not excessive. You need to make sure that the total cost of the product does not become excessive because of the intellectual property rights involved." 
Two managers from a large technology vendor explicitly confirmed that maximum royalty rates are usually agreed during licensing negotiations among companies to avoid royalty stacking specially in the case of patent pool licensing: "Our company usually pursues royalty rates agreements at around $8 \%$ of the total cost of the product, for instance a smartphone".

A policy of limiting royalty rates accrued from the licensing of essential patents (i.e. maximum royalty rate mechanism) is considered beneficial especially at the collective level (Median Q $4_{4}=4$ ) with less support at the firm level (Median Q3 $3_{4}=3$ ).

Managers exhibit stronger valuations for maximum royalty rate mechanism both for their firms and the collective $(5.45,10.85)$ according to Table 5 . On a similar manner, technology consumers exhibit larger odds of scoring maximum royalty rate as an important mechanism compared to technology producers $(3.7,4.05)$, clearly reflecting the beneficial effect of having a cap on the expected costs associated with acquiring the rights to have access to patent pools. All of the above indicate support for Hypothesis H1.c.

\subsection{Collaborative innovation \&\& competition}

Table 6 reports summary statistics for the mayor variables considered in regards to competition, measured via questions $\mathrm{Q} 1, \mathrm{Q} 2, \mathrm{Q} 5, \mathrm{Q} 6, \mathrm{Q} 7, \mathrm{Q} 9$ and $\mathrm{Q} 9^{\prime}$.

Table 6. Impact of mechanisms for competition in 3GPP (descriptive analysis)

Quantile

\begin{tabular}{|c|c|c|c|c|c|c|c|}
\hline & \multirow[b]{2}{*}{ Variable } & \multirow[b]{2}{*}{$\mathrm{n}$} & \\
\hline & & & Min & .25 & Median & .75 & Max \\
\hline \multirow{2}{*}{$\begin{array}{l}\text { Essential patents } \\
\text { (private) }\end{array}$} & $\mathbf{Q} \mathbf{1}_{1}$ & 87 & 3.00 & 3.00 & 4.00 & 4.00 & 5.00 \\
\hline & $\mathbf{Q 2}_{1}$ & 87 & 3.00 & 3.00 & 4.00 & 4.00 & 5.00 \\
\hline \multirow{3}{*}{$\begin{array}{l}\text { Essential patents } \\
\text { (collective) }\end{array}$} & Q5 ${ }_{1}$ & 87 & 2.00 & 3.00 & 3.00 & 4.00 & 5.00 \\
\hline & $\mathrm{Q6}_{1}$ & 87 & 1.00 & 3.00 & 3.00 & 4.00 & 5.00 \\
\hline & $Q 7_{1}$ & 87 & 2.00 & 3.00 & 3.00 & 4.00 & 5.00 \\
\hline \multirow{4}{*}{$\begin{array}{l}\text { FRAND } \\
\text { (private) }\end{array}$} & $\mathbf{Q 1}_{\mathbf{2}}$ & 87 & 3.00 & 4.00 & 4.00 & 5.00 & 5.00 \\
\hline & $\mathbf{Q 1}_{3}$ & 87 & 2.00 & 3.00 & 4.00 & 4.00 & 5.00 \\
\hline & $\mathbf{Q 2}_{2}$ & 87 & 3.00 & 3.00 & 4.00 & 4.00 & 5.00 \\
\hline & $\mathrm{Q2}_{3}$ & 87 & 2.00 & 3.00 & 3.00 & 4.00 & 5.00 \\
\hline FRAND & Q5, & 87 & 3.00 & 3.00 & 4.00 & 4.00 & 5.00 \\
\hline
\end{tabular}




\begin{tabular}{|c|c|c|c|c|c|c|c|}
\hline \multirow[t]{5}{*}{ (collective) } & $\mathrm{Q5}_{3}$ & 87 & 1.00 & 3.00 & 4.00 & 4.00 & 5.00 \\
\hline & $\mathrm{Q6}_{2}$ & 87 & 1.00 & 3.00 & 4.00 & 4.00 & 5.00 \\
\hline & $\mathrm{Q6}_{3}$ & 87 & 1.00 & 3.00 & 4.00 & 4.00 & 5.00 \\
\hline & $\mathrm{Q7}_{2}$ & 87 & 2.00 & 3.00 & 3.00 & 4.00 & 5.00 \\
\hline & $\mathrm{Q7}_{3}$ & 87 & 2.00 & 3.00 & 3.00 & 4.00 & 5.00 \\
\hline \multirow{2}{*}{$\begin{array}{c}\text { Maximum } \\
\text { Royalty rate } \\
\text { (private) }\end{array}$} & $\mathrm{Q1}_{\mathbf{4}}$ & 87 & 2.00 & 4.00 & 4.00 & 4.00 & 5.00 \\
\hline & $\mathbf{Q 2}_{4}$ & 87 & 2.00 & 3.00 & 4.00 & 4.00 & 5.00 \\
\hline \multirow{3}{*}{$\begin{array}{c}\text { Maximum } \\
\text { Royalty rate } \\
\text { (collective) }\end{array}$} & $\mathrm{Q5}_{4}$ & 87 & 2.00 & 3.00 & 4.00 & 4.00 & 5.00 \\
\hline & $\mathrm{Q6}_{4}$ & 87 & 1.00 & 3.00 & 4.00 & 4.00 & 5.00 \\
\hline & $\mathrm{Q7}_{4}$ & 87 & 1.00 & 3.00 & 3.00 & 4.00 & 5.00 \\
\hline \multirow{2}{*}{$\begin{array}{l}\text { 3GPP and } \\
\text { competition }\end{array}$} & Q9 & 87 & 2.00 & 3.00 & 4.00 & 4.00 & 5.00 \\
\hline & Q9' & 87 & 3.00 & 3.00 & 4.00 & 4.00 & 5.00 \\
\hline
\end{tabular}

\subsubsection{Essential patents mechanism}

Results of Table 6 indicate that, essential patents which are considered beneficial at the firm level (Median: $\mathrm{Q}_{1}=4, \mathrm{Q} 2_{1}=4$ ), are however, not perceived as beneficial at the collective level (Median: $\left.\mathrm{Q} 5_{1}=3, \mathrm{Q} 6_{1}=3, \mathrm{Q} 7_{1}=3\right)$. This latter result indicates some potential causality between the essential patent mechanism and the inability of $3 \mathrm{GPP}$ as a collective to compete against other technologies provided by the market.

In order to further investigate this phenomenon collected market information on essential patents, also specific questions during the interviews were formulated.

Our interview data analysis suggests reasons why this might be the case. A number of interviewees with relevant positions in 3GPP (technology delegates) pointed out that the process of defining which patent becomes essential is cumbersome and subject to large negotiation processes, "... this slows down the agreement process and causes 3GPP to stall in the definition of new technologies and products...", "...The process of defining what becomes an essential patent has worked incredibly well in some parts of the mobile ecosystem (radio technologies) however it is not as efficient in other parts in which markets are much more dynamic... as is the case in internet services or end customer applications .... a clear example is Skype, a non-3GPP technology that has prevailed over 3GPP-defined alternatives". 
A prominent member of ETSI stated that an overarching problem with the actual process of essential patenting is the fact that firms are free to claim essentiality to their patents as they see fit thus leaving room for an ex-post interpretation of essentiality (and royalties involved) and in many cases to litigation in court. Current reality around patent litigation in the mobile industry confirms this situation (Economist 2011, 2012; FT 2012; Forbes 2012, 2013a).

An analysis of the distribution of essential patents within 3GPP reveals a high concentration of this kind of patent in large, technology intensive, multinationals, in detriment to others such as small firms or technology consumers such as telecom operators or smartphone manufacturers (see Table 7). Therefore it is reasonable to believe in the existence of some power asymmetries within 3GPP induced by the ownership, or lack of, essential patents as well as the process of negotiating ex-post what is considered "essential".

Table 7. Essential patent distribution in 3GPP (LTE technologies)

\section{$4^{\text {th }}$ generation mobile families declared}

\section{Patents considered essential}

\section{Percentage}

54.29

7.62

1.90

0.95

2.86

0.95

0.95

0.95

0.95

0.00

0.95

DirecTV

1
210

1
105

One interviewee recognized the inherent asymmetries in the essential patent mechanism: "if two large vendors own essential patents they exchange them and everyone is happy..... however patent purchasers need to pay for access to patent portfolios.... and this is where you get the tension... Essential patents are not perfect but it is the best mechanism we have at the moment".

Hence we obtain partial support of the essential patent mechanism as a competition enabler in private-collective contexts (H2.b).More specifically the results of this section suggest that, being essential patenting relevant for competition purposes, the processes as defined in 3GPP slow-down technology commercialization as well as induce ex-post subjective interpretation (and hence litigation). 


\subsubsection{FRAND mechanism}

FRAND licensing, which becomes compulsory in the case of essential patents, is a measure to counter the power granted to the owner of an essential patent. In this sense FRAND is a competition enabler as it precludes monopolistic practises by forcing companies to grant licenses on a similar basis to every firm, moreover the obligation to license on a FRAND basis is extended not just to 3GPP members but also to every external firm. The obligation to broaden the FRAND scope to external parties constitutes an important feature to enact the concept of open patent pools, an important requisite in antitrust legislation.

The results presented in Table 6 reveal a strong support of FRAND as a relevant mechanism to facilitate competition both at the firm level (Median: $Q 1_{2}=4, Q 1_{3}=4, Q 2_{2}=4, Q 2_{3}=3$ ) and the collective one (Median: $Q 5_{2}=4, Q 5_{3}=4, Q 6_{2}=4, Q 6_{3}=4$ ). The above presented results thus provide support for FRAND as a mechanism that is relevant in facilitating competition in private-collective institutions (H2.a).

\subsubsection{Maximum royalty rate}

In regards to the impact of maximum royalty rate policies on competition, the results provide support for hypotheses H2.c, both at the firm and the collective level (Median Q1 $1_{4}=4, Q 2_{4}=4$ ) and $\left(\mathrm{Q} 5_{4}=4, \mathrm{Q} 6_{4}=4, \mathrm{Q} 7_{4}=3\right)$ respectively. This confirms maximum royalty rate policy as a beneficial instrument that facilitates competition in private-collective institutions.

\section{Discussion, limitations and conclusions}

The results of this paper extend existing theory on the private-collective model of innovation by characterizing how collective innovation takes place in current technological contexts such as the Internet, and mobile. Earlier work on private-collective models of innovation (von Hippel \& von Krogh 2006; Alexy \& Reitzig 2013; Boudreau 2012) has not examined empirically the extent to which IP rights policy implementation affected members ability to innovate and to compete. Our study highlights the importance of three mechanisms: FRAND, essential patents and maximum royalty rate to overcome patent fragmentation and patent holdup.

In this sense this paper reveals a set of mechanisms whereby private-collective organizations effectively manage two trade-offs: (1) the conflicting interests between the private (i.e. firms) and the collective (e.g. standards setting and its adoption by the market) as a whole, and (2) conflicts of interest between collaborative innovation and antitrust authorities.

With regards to the first trade-off, essential patenting is a mechanism providing legal and technical context upon which private value capture and technological development can occur whereas compulsory FRAND licensing and maximum royalty rate policy as mechanisms required to ensure value creation at the collective level via cumulative innovation (Bessant 1998) and the development of patent pools (Lerner \& Tirole 2002b).

With regards to the second trade-off, the limiting power of both FRAND compulsory licensing and maximum royalty rate policy lead to economic benefits and efficiency gains within the collective, moreover the fact that compulsory FRAND applies also to external firms constitutes an open patent 
pool system whereby non-affiliated firms can license technologies developed by the privatecollective.

\subsection{Limitations}

As with every empirical study, our analysis is subject to several data-related limitations. First, our results are obtained in one large, albeit specific, context (3GPP). Further research on privatecollective as a model of innovation could test the results of this paper in other settings for instance the internet engineering task force (IETF) or the Apache software community.

The lack of sufficient responses from small firms limits the conclusions of this paper to multinationals, antitrust authorities and standardization agencies. In this regard, we would suggest future analysis on the ability of small firms to protect their innovations and compete in privatecollectives dominated by large multinationals.

In regards to the instruments for the management of IPrights within the private-collective, this paper only considers three of them (i.e. FRAND, essential patenting and maximum royalty rate), there are however other important mechanisms required to reach consensus and avoid negotiation stalling that would deserve further analysis.

Market data (GSA 2013), the results of the survey and interviews conducted provide evidence on the ability of 3GPP to compete worldwide against technological alternatives. An unexpected insight emerging from two interviews is the existence of two clearly separated technological families within 3GPP, one corresponding to technologies associated with radio communications (termed as the "lower layer") and other corresponding with internet services and mobile applications ("upper layer"). Engineers expressed some concerns on the adequacy of the 3GPP model of innovation in the upper layer as, according to them, the rapid technological pace in the case of internet services rendered 3GPP not agile enough to respond to the market. This apparent inability of 3GPP to compete in agile markets might have some relationship with the observed lack of small firms involved in 3GPP compared to other private-collectives such as the open source movement (von Hippel \& von Krogh 2003, 2006 ; von Krogh et al. 2003 ) or Android (Tilson et al. 2012).

\subsection{Implications for Management theory}

This study contributes to the private collective literature as it is the first, to our knowledge, that explores empirically how the management of IP rights affects the ability of a private collective organization to both innovate and compete. We have found that the manner in which IP rights instruments are implemented in practice has a profound impact on shaping the process and the outcome of collective innovation in private collective organizations.

The literature on the management of IPrights has focused mostly on standard-setting organizations, and the majority of these studies focus on single mechanisms, which do not allow researchers to explore the interaction between these IP rights mechanisms. Our results reveal strong complementarity between FRAND, essentiality and royalty revenue structures. Moreover we have found that the manner in which these mechanisms are implemented in practice (i.e. before or after standard adoption takes place) have a profound impact on their effectiveness. 
Previous research (Treacy \& Lawrance 2008) has highlighted inherent weaknesses in the FRAND mechanism, focusing on its inherent ambiguity. The results of this paper however support FRAND as an effective mechanism in the way it is currently implemented in 3GPP. In this 3GPP case, participants concerns lie not in FRAND but in the ex-post interpretation of essentiality by licensees. This would reinforce the necessity of integrative perspectives in order to gain a complete understanding of current regimes for collaborative innovation (and their shortcomings).

Following Gulati (1998) the governance structure of the private-collective can be defined as the formal contractual structure participants use to formalize the partnership. Choices of governance structure are moderated by appropriability concerns (Pisano et al. 1988; Pisano 1989; Balakrishnan \& Koza 1993) as well as coordination costs resulting from the extent of interdependence expected by the partners.

The results of our research confirm both appropriability and coordination costs as determinants in the choice of governance structure and the ability to innovate. In addition, we find that power asymmetries due to firm's size or IP right ownership do also play a moderating role in how the governance structure is designed.

As far as the 3GPP is concerned, its governance structure could be assimilated to a contractual alliance whereby members of the partnering firms work together within their organizational boundaries (Gulati 1998). 3GPP facilitates unidirectional agreements such as licensing, secondsourcing, distribution agreements as well as bidirectional agreements such as joint contracts and technology exchanges.

Unlike conventional contractual alliances though, the 3GPP provides administrative hierarchies with rules and responsibilities for each member of the private-collective (e.g. FRAND regime for essential patents) thereby resembling a joint venture mechanism of innovation. In this case administrative hierarchy is provided via consensus-based processes for technology development and well defined (albeit not necessarily well enforced) policies for the management of intellectual property rights.

Our paper thus provides insights on the challenges arising in governance structures within federations of innovators which are also competitors, and inform related scholarly conversations on the importance and difficulty to formulate and implement governance structures that maintain incentives to innovate privately as well as collectively, in the face of technological and relational uncertainty.

The results of our study also hold implications for the various literatures that are addressing the issue of collective innovation. Task modularization (Sanchez 1995; Baldwin \& Clark 2000), the pervasiveness of information and communication technologies, combined with the wide global distribution of skills and knowledge, are displacing the locus of innovation from within firms to networks of innovators (Baldwin \& Von Hippel 2011; Chesbrough 2003).Beyond the literature on private collective models, literatures on technological platforms (Gawer \& Cusumano 2002; Gawer \& Henderson 2007; Gawer 2009, 2014; Boudreau 2010; Boudreau \& Hagiu 2009; Eisenmann 2008; Eisenmann et al. 2011, Nambisan and Sawhney 2011;Tiwana et al. 2010), innovation ecosystems (Adner \& Kapoor 2010), ecologies of innovation (Dougherty \& Dunne 2011) and meta-organizations (Gulati et al. 2012), all examine the modalities of organization, management, and governance of network of innovators. 


\subsection{Implications for policy makers:}

As revealed in the case of 3GPP some forms of private-collective can mitigate limitations of current regulation of intellectual property rights (e.g. patent system) and effectively articulate sustainable regimes for collective innovation. Antitrust authorities are acknowledging the important role played by private-collective modes of innovation in complex technological regimes by explicitly granting legal coverage (AMC 2007; Balto 2004).

The results of the interviews conducted and the survey support 3GPP as an institution that nurtures innovation (medians: $\mathrm{Q} 8=4, \mathrm{Q}^{\prime}=4$ ) while allowing competition both within $3 \mathrm{GPP}$ and in external markets (medians: $Q 9=4, Q 9=4$ ). 3GPP though, seems to have a tendency to impede technology differentiation from firms involved within the private-collective (medians: $Q 7_{1-4}=3$ ). This phenomenon, which is inherent to any standardization process, whereby technological consensus is needed may force firms to compete just on price rather than on technological performance. Therefore private-collective institutions need to establish a delicate balance between two extremes: complete ex-ante specification versus dynamic ex-post consensus building. Remaining on the first extreme would lead to lower innovation rates and competition based on price whereas the second extreme would lead to competition based on features (and increased litigation which, if excessive, might become counter-productive to innovation).

According to some of the experts interviewed, current regulation of the mobile industry can slow down the development of new technologies as, in contrast to the internet industry, mobile services are required to have extremely high levels of reliability. In this sense policy making could differentiate between critical technologies (e.g. radio access, antennae, basic communication services) and non-critical ones (e.g. mobile applications, multimedia services) in order to establish a tiered approach to mobile regulation.

The analysis of 3GPP reveals that small technological firms are practically absent in the development of mobile standards with only 30 small firms (out of 200 in total, 3GPP 2013) and no essential patents to negotiate with (Table 1). Recent results find an increasing role played by small parties in the resulting ability to innovate (Von Hippel \& von Krogh 2003; Lakhani \& von Hippel 2003, Lakhani et al. 2013; Boudreau 2012), further research could investigate why other instances of privatecollective (e.g. software, internet, smartphone ecosystems) exhibit larger presence of small firms and if there exists any potential causality between the presence of small firms and the resulting innovation ability of the private-collective.

Related theory on standards and technology development supports the importance of the essentiality concept as a key mechanism to facilitate technical interoperability (and resulting economies of scale and scope). The results of our research, however present a more nuanced relationship between essential patenting and the resulting ability of the focal firm to innovate and compete. In the case of 3GPP essential patenting adequately helps firms to develop new technologies (hypothesis H1.b,section 4.1.1) on the other hand this mechanism seems to constrain the ability to compete, especially at the collective level (hypothesis H2.b, section 4.2.1).

The experience of 3GPP shows us that the manner in which IPrights policies are implemented in practice do have a profound effect on private-collective organizations. Contrary to FRAND licensing, which is completely specified and agreed prior to any technology commitment (i.e. standard 
development), the attribution of essentiality remains open to ex-post interpretation. Interestingly 3GPP does not mandate which patents become essential, as a result and according to a high level manager at 3GPP "almost every patent owner in 3GPP claim to have essential patents... the problem arises whenever a licensee does not agree on that essentiality status". This would explain the increasing rates of litigation among firms in the mobile industry with prominent examples such as Samsung versus Ericsson (WSJ 2012; 2013), 3GPP participants, or Samsung versus Apple (Forbes 2012).

Litigation mechanisms, not necessarily indicative of a dysfunctional innovation regime, at present time are being over-abused specially by firms with no real involvement in technology development or commercialization. In this sense the 3GPP could, (1) adopt a more active role in the assertion of the essentiality aspect of patents in order to avoid ex-post interpretation by firms and (2) implement more efficient mechanisms to ensure transparency of patent ownership in the spirit of section 4 of the new innovation act (HR2013).

We have revealed that a practical solution to the limitations of current essential patenting has been found and implemented in the context of 3GPP: it consists in associating essential patenting policies to an ex-ante maximum royalty rate policy, which limits ex-post opportunistic behavior. This practical solution raises some concerns however, given the possibility of maximum royalty rate to be interpreted as anti-competitive by current antitrust regulation, and its traditional condemnation on both sides of the Atlantic in standard-setting processes (Schmalensee 2009).

We therefore raise the question of re-examining the potentially negative impact of antitrust regulation on collective innovation. The adoption of this practical solution, currently advocated by a number of firms involved in 3GPP (LTE 2008), would require modifications in antitrust regulation and a more flexible approach to public policing of collective innovation.

While the paper does not propose a definitive answer to his question, it contributes to the innovation policy debate on the reform of the patent system and antitrust regulation (AMC 2007; Wright 2009; Zoettl et al. 2009) especially in the mobile sector (Balto 2004), by providing empiricallybased insights in favor of limiting the potentially negative impact of some aspects of competition policy on specific collective innovation challenges. This is a topical issue, as, in response to requests from relevant organizations (IEEE 2002) public bodies, especially in the USA, are starting to explore alternatives to conventional antitrust enforcement by suggesting among others an obligation on those firms submitting technologies to state the maximum royalty that will be sought in respect of any patents held (Barnett 2006, 2007; Masoudi 2007; Sidak 2008). In parallel, a number of firms in the mobile industry are leading initiatives aiming to supersede current limitations by explicitly suggesting maximum aggregate royalty levels for essential IPRs (e.g., single-digit percentage of sales price in the case of handsets and single-digit dollar amounts in the case of notebooks, LTE 2008).

The analysis presented in this paper, indicating that 3GPP members considered maximum royalty rate policies as beneficial, supports a more relaxed public policy in regards to maximum royalty rate negotiations and supports Schmalensee (2009) who suggests that, provided certain safeguards relating to the extent to which private-collective members can actually discuss the licensing terms are in place, it should be acceptable for standards bodies to solicit provision of maximum royalty rates when a patented technology is submitted. 
Avenues for future research include further empirical studies and the development of gametheoretical models exploring the extent to which establishing predictable and more transparent maximum aggregate costs for licensing intellectual property rights might alleviate the problem of subjectivity in an ex-post interpretation of the essentiality concept either by firms (Wright 2009; Forbes 2012, 2013a, 2013b) or by governments overruling a court's decision (FT 2013).

\section{References}

Adner, R., R. Kapoor. 2010. Value creation in innovation ecosystems: how the structure of technological interdependence affects firm performance in new technology generations, Strategic Management Journal 31(3), 306-333.

Alexy, O., M. Reitzig. 2013. Private-collective innovation, competition, and firms' counterintuitive appropriation strategies, Research Policy 42(4), 1325-1340.

AMC 2007.Antitrust Modernization Commission: report and recommendations. Antitrust Modernization Commission. Last Accessed August 2013.

Arora, A., Fosfuri, A., A. Gambardella.2004. Markets for technology: The economics of innovation and corporate strategy. Cambridge, Mass.: MIT Press.

Balakrishnan, S., M.P. Koza. 1993. Information asymmetry, adverse selection and joint ventures: theory and evidence , Journal of Economic Behaviour and Organization, 20(1), 99-117.

Baldwin, C.Y., K.B. Clark.2000. Design rules: The power of modularity. Vol. 1. Cambridge, Mass.: MIT Press.

Baldwin, C.Y., E. von Hippel. 2011. Modeling a paradigm shift: from producer innovation to user and open collaborative innovation, Organization Science 22(6), 1399-1417.

Balto, D.A. 2004. The antitrust analysis of the 3G patent platform, Antitrust and Intellectual Property 5(1), 16-24.

Barnett, O.2006.Letter to Robert A. Skitol. Available at http://www.usdoj.gov/atr/public/busreview/219380.pdf

Barnett, O.2007.Letter to Michael A. Lindsay. Available at http://www.usdoj.gov/atr/public/busreview/222978.pdf

Bekkers, R., Bongard, R., A.Nuvolari. 2011. An empirical study on the determinants of essential patent claims in compatibility standards, Research Policy 40(7), 1001-1015.

Bessant, J. 1998. Developing continuous improvement capability, International Journal of Innovation Management 2(4), 409-429.

Boudreau, K. J.2010. Open platform strategies and innovation: granting access vs. devolving control, Management Science 56(10), 1849-1872.

Boudreau, K.J. 2012.Let a thousand flowers bloom? An early look at large numbers of software app developers and patterns of innovation, Organization Science 23(5), 1409-1427.

Boudreau, K. J., A. Hagiu. 2009. Platform rules: multi-sided platforms as regulators, in A. Gawer, (ed.) Platforms, Markets and Innovation. Edward Elgar, Cheltenham, UK and Northampton, Mass., 163-191.

Chesbrough, H. 2003. Open Innovation: The new imperative for creating and profiting from technology. Harvard Business Press.

Chiao, B., Lerner, J., J. Tirole. 2007. The rules of standard-setting organizations: an empirical analysis, RAND Journal of Economics 38(4), 905-930.

Cohen, W.M., Nelson, R.R., J.P. Walsh. 2000. Protecting their intellectual assets: appropriability conditions and why US manufacturing firms patent (or not), National Bureau of Economic Research. No. w7552. 
Das, T.K., B.S. Teng. 2000. A resource-based theory of strategic alliances, Journal of Management 26(1), 31-61.

De Jong, J. P., Kalvet, T., W. Vanhaverbeke. 2010. Exploring a theoretical framework to structure the public policy implications of open innovation, Technology Analysis \& Strategic Management 22(8), 877-896.

Dougherty, D., D.D. Dunne. 2011. Organizing ecologies of complex innovation, Organization Science 22(5),12141223.

EC.2010. http://ec.europa.eu/competition/consultations/2010_horizontals/guidelines_en.pdf

ETSI. 2013 Rules of procedure. http://www.etsi.org/images/etsi ipr-policy.pdf. Last accessed 2013.

Ebersberger, B. 2011. Open innovation in Europe: effects, determinants and policy. European Commission.

Economist.2013. Patent reform: Obama goes troll-hunting. The Economist

Economist.2012a. Patents and mobile devices, FRAND or foe? The Economist

Economist.2012b. Global mobile usage.SIM Earth . The Economist

Economist.2011. Intellectual property and mobile devices. World patent war 1.0. The Economist

Eisenmann, T.R. 2008. Managing proprietary and shared platforms, California Management Review 50(4), 31-53.

Eisenmann, T.R., Parker, G., M. Van Alstyne. 2011. Platform envelopment, Strategic Management Journal 32(12), 1270-1285.

Enkel, E. Gassmann, O., H. Chesbrough. 2009. Open R\&D and open innovation: exploring the phenomenon, R\&D Management 39(4), 311-316.

Farrell, J., Hayes,J., Shapiro, C., T. Sullivan. 2007. Standard setting, patents, and hold-up, Antitrust Law Journal 74(3), 603-670.

Flanagan, K., Uyarra, E., Laranja, M. 2011. Reconceptualising the 'policy mix' for innovation, Research Policy 40(5), 702-713.

Fischer, T., J. Henkel. 2013. Complements and substitutes in profiting from innovation-A choice experimental approach, Research Policy 42(2), 326-339.

Fitzgerald, B. 2006. The transformation of open source software, MIS Quarterly 30(3), 587-598.

Franzinger, M.R. 2003.Latent dangers in a patent pool: The European Commission's approval of the $3 \mathrm{G}$ wireless technology licensing agreements, California Law Review 91 (6), 1693-1728.

FT.2012. The battleground of choice in patent wars. Financial Times

FT.2013. Obama overturns Apple import ban. Financial Times

Forbes.2012 Ericsson Sues Samsung: Does Apple Therefore Benefit? .Forbes

Forbes.2013a. Apple: Investors Calm Over Possible Partial iPhone, iPad Ban. Forbes

Forbes.2013b. The Great Mobile Takeover. Forbes

Garud, R., A. Kumaraswamy.1993. Changing competitive dynamics in network industries: an exploration of Sun Microsystems' open systems strategy. Strategic Management Journal 14(5), 351-369.

Gawer, A. 2014. Bridging differing perspectives on technological platforms: toward an integrative framework, Research Policy (in press).

Gawer, A. 2009. Platforms, markets and innovation. Edward Elgar : Northampton, US and Cheltenham, UK. 
Gawer, A., M.A Cusumano. 2002. Platform Leadership: How Intel, Microsoft and Cisco drive industry innovation. Boston: Harvard Business School Press.

Gawer, A., M.A. Cusumano. 2008. How companies become platform leaders. MIT/Sloan Management Review 49(2), 28

Gawer, A., R. Henderson. 2007. Platform owner entry and innovation in complementary markets: evidence from Intel, Journal of Economics \& Management Strategy 16(1), 1-34.

Gawer, A., T. Cowen. 2012. Competition in the Cloud: unleashing investment and innovation within and across platforms, Communications \& Strategies, 85.

GSA. 3GPP market data .Retrieved from: http://www.gsacom.com/about/index.php4. Last accessed July 2013.

Gulati, R.1995. Does familiarity breed trust? The implications of repeated ties for contractual choice in alliances, Academy of Management Journal 38(1), 85-112.

Gulati, R.1998. Alliances and networks, Strategic Management Journal 19(4), 293-317.

Gulati, R., Puranam, P., M. Tushman. 2012. Meta-organization design: rethinking design in interorganizational and community contexts, Strategic Management Journal 33(6), 571-586.

Hagedoorn, J. 2002. Inter-firm R\&D partnerships: an overview of major trends and patterns since 1960., Research Policy 31(4), 477-492.

Hagedoorn, J., Link, A.N., N.S. Vonortas. 2000. Research partnerships, Research Policy 29(4), 567-586.

Hovenkamp, H. 2007. Standards ownership and competition policy, Boston College Law Review 48(1), 87-109.

Hovenkamp, H. 2005. The antitrust enterprise: Principle and execution. Cambridge, Mass.:Harvard University Press.

Howells, J.2006. Intermediation and the role of intermediaries in innovation, Research policy 35(5), 715-728.

HR. 2013. Innovation act . House of representatives USA. http://www.gpo.gov/fdsys/pkg/BILLS113hr3309ih/pdf/BILLS-113hr3309ih.pdf . Last accessed September 2013.

Huizingh, E.K., 2011. Open innovation: state of the art and future perspectives, Technovation 31(1), 2-9.

lansiti, M., R Levien. 2004. Strategy as ecology, Harvard Business Review 82(3), 68-81.

IEEE. Standards Association (IEEE-SA), 2002, 'Comments Regarding Competition and Intellectual Property,' April 17, available at http://www.ftc.gov/os/comments/intelpropertycomments/ieee.pdf. (Last accessed August 2013)

Joshi, A.M., A. Nerkar. 2011. When do strategic alliances inhibit innovation by firms? Evidence from patent pools in the global optical disc industry, Strategic Management Journal 32(11), 1139-1160.

Lakhani, K.R., Boudreau, K.J., Loh, P.R., Backstrom, L., Baldwin, C., Lonstein, E., ... \& Guinan, E.C. 2013. Prizebased contests can provide solutions to computational biology problems. Nature biotechnology 31(2), 108-111.

Lakhani, K.R., E. von Hippel. 2003. How open source software works: free user-to-user assistance, Research Policy 32(6), 923-943.

Leiponen, A.E. 2008. Competing through cooperation: the organization of standard setting in wireless telecommunications, Management Science 54(11), 1904-1919.

Lemley, M.A. 2002. Intellectual property rights and standard-setting organizations. California Law Review 90(6), $1889-1980$

Lemley, M.A. 2007. Ten things to do about patent holdup of standards (and one not to). Boston College Law Review 48, 149. 
Lemley, M.A., C. Shapiro. 1991. Patent Holdup and Royalty Stacking. Texas Law Review 85.

Lerner, JJ., J.Tirole. 2002a. Some simple economics of open source. Journal of Industrial Economics 50(2), 197234.

Lerner, JJ., J. Tirole.2002b. Efficient patent pools, National Bureau of Economic Research.

Levy. C. Reid, B. 2011. Missing an open goal? UK public policy and open innovation, Big Innovation Centre report.

Lichtman, D. 2010. Understanding the RAND Commitment, Houston Law Review 47, 1023.

LTE . 2008. Wireless Industry Leaders commit to framework for LTE technology IPR licensing . Ericsson press release, available at: http://hugin.info/1061/R/1209031/249725.pdf

Lunnan, R., S.A. Haugland. 2008. Predicting and measuring alliance performance: a multidimensional analysis, Strategic Management Journal 29(5), 545-556.

Masoudi, G.F. 2007. Antitrust Enforcement and Standard Setting: The VITA and IEEE Letters and the 'IP2' Report speech . Available at http://www.justice.gov/atr/public/speeches/223363.htm

Morlacchi, P., B.R. Martin. 2009. Emerging challenges for science, technology and innovation policy research: A reflexive overview, Research Policy 38(4), 571-582

Nambisan, S., M. Sawhney. 2011. Orchestration processes in network-centric innovation: evidence from the field, Academy of Management Perspectives 25(3), 40-57.

Olk, P., C. Young. 1997. Why members stay in or leave an R\&D consortium: performance and conditions of membership as determinants of continuity, Strategic Management Journal 18(11), 855-877.

Osborn, R. N., and C.C. Baughn. 1990. Forms of interorganizational governance for multinational alliances Academy of Management Journal 33(3), 503-519.

Osterloh, M., S. Rota. 2007. Open source software development-Just another case of collective invention?, Research Policy 36(2), 157-171.

Park, S.H., G.R. Ungson. 2001. Interfirm rivalry and managerial complexity: a conceptual framework of alliance failure, Organization Science 12(1), 37-53.

Phelps, M., C. Milone. 2012. LTE Standard Essential Patents Now and in the Future. Article One partners limited, 555 Madison Avenue, New York.

Pisano, G. P., M. V. Russo, D. Teece. 1988. Joint ventures and collaborative arrangements in the telecommunications equipment industry .In D. Mowery (ed.), International Collaborative Ventures in U.S. Manufacturing. Ballinger, Cambridge, MA: 23-70.

Pisano, G. P. 1989. Using equity participation to support exchange: evidence from the biotechnology industry, Journal of Law, Economics and Organization 5(1), 109-126.

Rysman, M., T. Simcoe. 2008. Patents and the performance of voluntary standard-setting organizations. Management Science 54(11), 1920-1934.

Sanchez, R. 1995. Strategic flexibility in product competition, Strategic Management Journal 16(1), 135-159.

Shapiro, C. 2001. Navigating the patent thicket: Cross licenses, patent pools and standard setting, in Jaffe, A., Lerner, J., S. Scott Stern (eds), Innovation Policy and the Economy, Volume I, MIT Press, 119-150.

Shapiro, C. 2008. Patent reform: Aligning reward and contribution, in Innovation Policy and the Economy, Volume 8. University of Chicago Press,111-156. 
Scherer, F.M., D. Ross. 1990. Industrial market structure and economic performance. University of Illinois at Urbana-Champaign's Academy for Entrepreneurial Leadership Historical Research Reference in Entrepreneurship.

Schmalensee, R. 2009. Standard setting, innovation specialists and competition policy, The Journal of Industrial Economics 57(3), 526-552.

Sidak, J.G. 2008. Patent holdup and oligopsonistic collusion in standard-setting organizations, Journal of Competition Law and Economics 5(1),123-188.

Somaya, D., Teece, D.J., S. Wakeman. 2011.Innovation in multi-invention contexts: mapping solutions to technological and intellectual property complexity, California Management Review 53(4), 47-79.

Somaya, D. 2003.Strategic determinants of decisions not to settle patent litigation, Strategic Management Journal 24(1), 17-38.

Stuermer, M., Spaeth, S., G. Von Krogh. 2009. Extending private-collective innovation: a case study, $R \& D$ Management 39(2), 170-191.

Teece, D.J.2006.Reflections on 'Profiting from innovation', Research Policy 35(8), 1131-1146.

Teece, D.J. 1992. Competition, cooperation, and innovation: Organizational arrangements for regimes of rapid technological progress, Journal of Economic Behavior\& Organization 18(1), 1-25.

Teece, D. J. 1986. Profiting from technological innovation: Implications for integration, collaboration, licensing and public policy, Research Policy 15(6), 285-305.

Tilson, D., Sorensen, C., K.Lyytinen. 2012. Change and control paradoxes in mobile infrastructure innovation: The Android and iOSmobile operating systems cases, System Science (HICSS), 2012 45th Hawaii International Conference on. IEEE.

Tiwana, A., Konsynski, B., A.A. Bush.2010. Research Commentary - Platform evolution: Co-evolution of platform architecture, governance and environmental dynamics, Information Systems Research 21(4), 675-687.

Treacy, P., S.Lawrance. 2008. FRANDly fire: are industry standards doing more harm than good? Journal of Intellectual Property Law \& Practice 3(1), 22-29.

USITC.Inv. No. 337-TA-794.U.S. International Trade Commission. (2013)

Van de Vrande, V., De Jong, J.P., Vanhaverbeke, W., M. De Rochemont. 2009. Open innovation in SMEs: trends, motives and management challenges, Technovation 29(6), 423-437.

Viscusi, W.K., Vernon, J., J.E. Harrington Jr. 2005. Economics of regulation and antitrust, Vol. 4. Cambridge, Mass: MIT Press.

Von Hippel, E., G. Von Krogh. 2003. Open source software and the private-collective innovation model: issues for organization science, Organization science 14(2), 209-223.

Von Hippel, E., G. Von Krogh. 2006. Free revealing and the private-collective model for innovation incentives, $R \& D$ Management 36(3), 295-306.

Von Krogh, G., Spaeth, D., K.R. Lakhani. 2003. Community, joining, and specialization in open source software innovation: a case study, Research Policy 32(7), 1217-1241.

Whish, R., D. Bailey. Competition law. Oxford: Oxford University Press.

Williamson, O.E. 1998. The economic institutions of capitalism. New York: Free Press,

Wooldridge, J.M. 2012.Introductory econometrics: a modern approach. Cengage Learning.

Wright, J.D. 2009. Why the Supreme Court was correct to deny Certiorari in FTC v. Rambus, Global Competition Policy, release March-09 (2). 
WSJ.2012. Ericsson Files Patent Claim Against Samsung . Wall Street Journal. 27 November 2012, http://online.wsj.com/news/articles/SB10001424127887324469304578144592724642244

WSJ 2013.Samsung Countersues Ericsson. Wall Street Journal, 20 March 2013, http://online.wsj.com/news/articles/SB10001424127887324103504578371902710149908

Yasuda, H. 2005. Formation of strategic alliances in high-technology industries: Comparative study of the resource-based theory and the transaction-cost theory. Technovation 25(7), 763-770.

Yoo, Y., Boland, R. J., Lyytinen, K., A. Majchrzak.2012. Organizing for innovation in the digitized world, Organization Science, 23(5), 1398-1408.

Zoettl, J. Evrard, S. Oliver, G. McDonald, B. Harris, S. Watanable, S. Miyakawa, H.Wang, P. Y. Zhang. 2009. Recent developments in the United States, EU and Asia at the intersection of antitrust and patent law, Antitrust Chronicle 3.

3GPP. 2077.3GPP Scope and Objectives .Retrieved from http://www.3gpp.org/ftp/Inbox/2008_web_files/3GPP_Scopeando310807.pdf.

3GPP. 2013a.The 3rd Generation Partnership Project (3GPP) .http://www.3gpp.org/About-3GPP.

3GPP. 2013b.3GPP WorkPlan. Retrieved from: http://www.3gpp.org/specifications/64-work-plan 
Innovation Policy within Private Collectives: Evidence on 3GPP's Regulation Mechanisms to Facilitate Collective Innovation

Special Issue in Technology Strategy and Technology Policy.

\author{
David Lopez-Berzosa ${ }^{1}$, \\ d.lopez-berzosa@exeter.ac.uk, \\ Annabelle Gawer ${ }^{2}$ \\ a.gawer@imperial.ac.uk
}

1. University of Exeter Business School, I.E. Business School

2. Imperial College London 